\title{
LECANIA MAKAREVICZIAE, A NEW LICHEN SPECIES FROM IRAN
}

\author{
M. Haji Moniri ${ }^{1}$, S. Y. Kondratyuk ${ }^{2}$ and P. P. G. van den Boom ${ }^{3}$ \\ ${ }^{1}$ Department of Biology, Faculty of Sciences, Mashhad Branch, Islamic Azad University \\ Mashhad,Iran; E-mail:m.h.moniri@mshdiau.ac.ir \\ ${ }^{2}$ M. H. Kholodny Institute of Botany, Tereshchenkivska str. 2, 01004 Kiev, Ukraine \\ E-mail:ksya_net@ukr.net \\ ${ }^{3}$ Arafura 16, 5691JA, Son, The Netherlands; E-mail: pvdboom@kpnmail.nl
}

(Received 16 June, 2015; Accepted 20 August, 2015)

\begin{abstract}
A new for science species Lecania makarevicziae differing from L. pallida in having knobby to squamulose, blastidiate thallus, in having larger apothecia, in having a dark violet-brown disc, in having a plane disc, in having (1-2-)3-septate ascospores with slightly distinct constrictions at the septum, as well as in the lack of dense bluish pruina on apothecium disc, from Iran and Turkmenistan, is described, compared with closely related taxa.
\end{abstract}

Key words: Asia, corticolous, lichenised ascomycetes, Ramalinaceae

\section{INTRODUCTION}

The genus Lecania is rather well represented in Asia. Nine species are mentioned in the checklist of Tajikistan (Kudratov and Mayrhofer 2002), 4 species are mentioned in Kazakhstan (Andreeva 1987) and 4 species are mentioned in Afghanistan (Steiner and Poelt 1987). The Lecania key of the former the USSR region including 30 species (16 of them Asian) was prepared by Makarevich (1971). Notes on some Asian Lecania species are made by various authors (Davydov and Printzen 2012, Kondratyuk et al. 2007, 2013, 2015a, b, 2016, Oxner 1929, van den Boom and Khodosovtsev 2004, van den Boom and Zedda 2000, etc.). The checklist of Iran mentioned 12 Lecania species (Seaward et al. 2004, 2008) and three more species were recently added (Haji Moniri et al. 2014). Several new species of Lecania are recently described from Korea (Kondratyuk et al. 2013, 2015b). Here we describe a new species of Lecania, L. makarevicziae, known from several localities of Iran and Turkmenistan. 


\section{RESULTS}

Lecania makarevicziae M. Haji Moniri, P. van den Boom et S. Y. Kondr.,
spec. nova (Fig. 1A-C)

Mycobank no.: MB 815813

Similar to Lecania pallida, but differs in having knobby to squamulose, blastidiate thallus, in having larger apothecia, in having dark violet-brown disc, in having plane disc, in having (1-2-)3-septate ascospores with slightly distinct constrictions at the septum, as well as in the lack of dense bluish pruina on apothecium disc.

Type: Iran: Razavi Khorasan province, $25 \mathrm{~km}$ SW of Mashhad, Torghabeh, Taraghdar village, $36^{\circ} 17^{\prime} \mathrm{N}, 59^{\circ} 19^{\prime} \mathrm{E}, 1,465 \mathrm{~m}$, covered with gardens, on bark of Morus nigra, Juglans regia, Corylus avellana and Fraxinus excelsior, growing mainly on the lower part of the old trees, and often associated with Physcia dimidiata (Arnold) Nyl., leg.: M. Haji Moniri, N. Shaabani and R. Mohammadi, 02.03.2013 (holotype: B; isotypes: KW-L, hb. M. Haji Moniri, hb. van den Boom).

Thallus ca $1 \mathrm{~cm}$ across, somewhat knobby to squamulose, or bullate; squamules $0.15-0.6(-0.8) \mathrm{mm}$ diam./across, very convex or uplifted, upper surface matt to somewhat shiny, grey to pale or dull greenish, rarely blastidiate; blastidia mainly hardly seen or indistinct, to 50-200 $\mu \mathrm{m}$ diam., observed only in some places.

Apothecia (0.3-)0.5-1.5(-1.7) $\mathrm{mm}$ in diam. and to $0.15 \mathrm{~mm}$ thick in the section, lecanorine, clearly constricted at base; thalline margin $0.1-0.15 \mathrm{~mm}$ thick, permanent or crenulated in parts, disc plane or somewhat concave at first to somewhat undulating at the overmature, dark brown or violetish brown, often white pruinose; thalline exciple to $100 \mu \mathrm{m}$ thick, with cortical layer better developed on underside to $40-50(-70) \mu \mathrm{m}$ thick, with matrix and palisade hyphae or mesodermatous paraplectenchymatous with cell lumina 7-10 $\times 4-5 \mu \mathrm{m}$; true exciple to $55 \mu \mathrm{m}$ wide in the uppermost lateral portion and to (15-)20-40 $\mu \mathrm{m}$ thick in the lower lateral and basal portions, with matrix, scleroplectenchymatous or pseudoprosoplectenchymatous (sensu Kondratyuk and Kärnefelt 1997), hyphae lumina to $3 \mu \mathrm{m}$ diam.; hymenium to 50 $\mu \mathrm{m}$ high; epihymenium brownish, paraphyses with distinctly swollen tips to 4-6(-7) $\mu \mathrm{m}$ diam., dark brown to black; subhymenium very thin, to $20 \mu \mathrm{m}$ thick, hyaline; asci (2-)8-spored; ascospores (1-2-)3-septate, hyaline, somewhat curved or straight, with slight constrictions at the septum to slightly twisted, (13-)15-18(-20)[-23] × (4-)4.5-5.5(-6) $\mu \mathrm{m}$.

Chemistry: In section epihymenium $\mathrm{K}+$ weakly violet.

Ecology: On bark of Morus nigra, Juglans regia, Corylus avellana and Fraxinus excelsior, growing mainly on the lower part of the old trees, and often associated with Physcia dimidiata, species of the genera Caloplaca and Megaspora. 
Etymology: It is named after Ukrainian lichenologist Maria F. Makarevych (in Latin "Makarevicz"), who has provided an important key to Asian Lecanias in 1971.

Distribution: So far it is known from scattered localities in Iran and Turkmenistan, Asia.
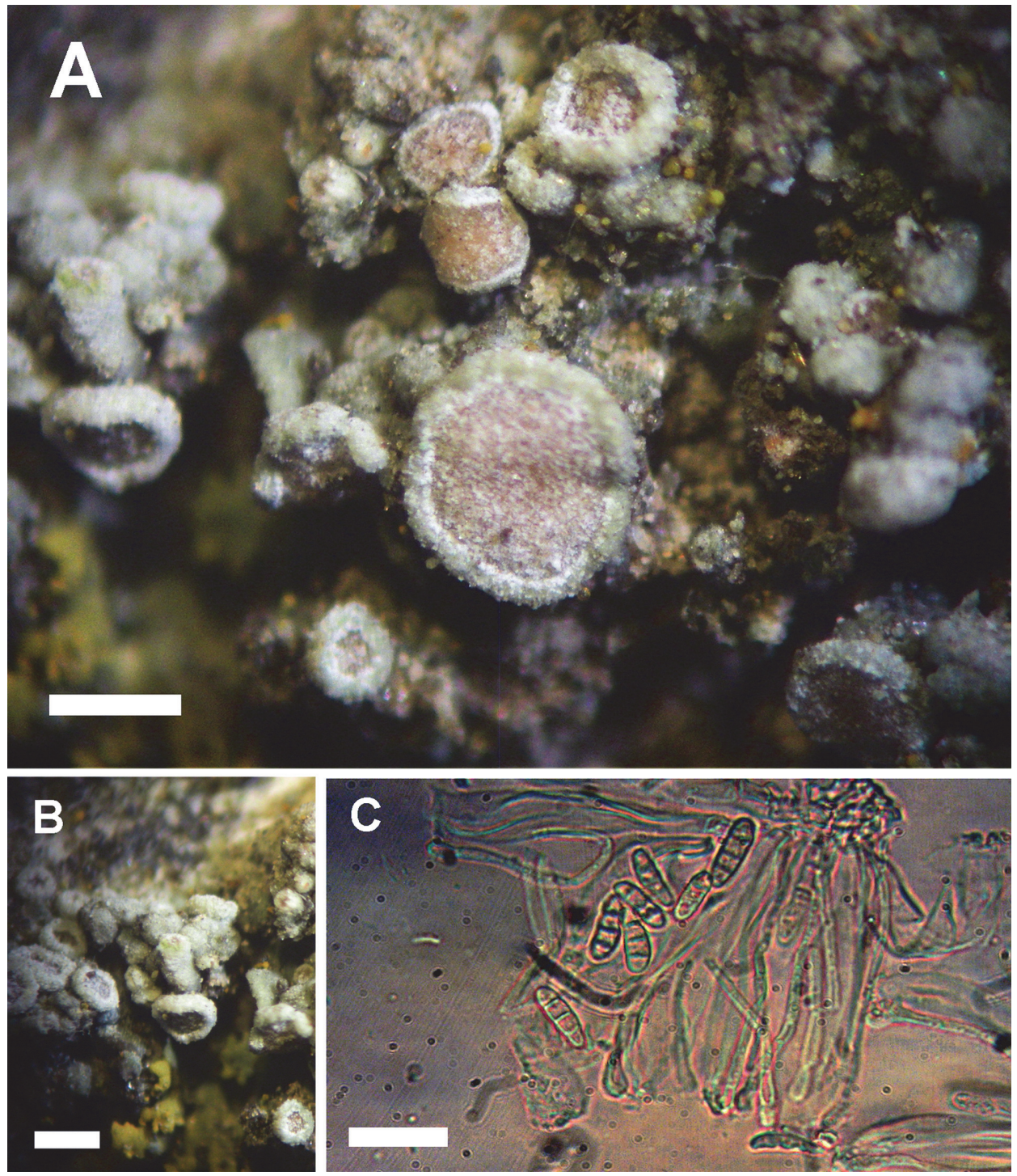

Fig. 1. Lecania makarevicziae (holotype). $\mathrm{A}=$ habitus with mature apothecia and thallus (scale: $0.5 \mathrm{~mm}$ ); $\mathrm{B}=$ habitus with bullate thallus and young apothecia (scale: $0.5 \mathrm{~mm}$ ); $\mathrm{C}=$ ascospores and paraphyses (scale: $20 \mu \mathrm{m}$ ) 
Taxonomic notes: Lecania makarevicziae is similar to Lecania pallida Tomin, known from Uzbekistan from twigs of Berberis, but differs in having knobby to squamulose, blastidiate thallus (vs. tiny granular to indistinct), in having larger apothecia (0.5-1.5(-1.7) $\mathrm{mm}$ vs. $0.5-1 \mathrm{~mm}$ across), in having dark violetish brown disc (vs. lightly brownish), in having plane disc (disc plane to subconvex with time), in having (1-2-)3-septate ascospores with slightly distinct constrictions at the septum (3-septate without constrictions), as well as in the lack of dense bluish pruina on apothecium disc.

From Lecania triseptata (Vain.) Zahlbr., rare arid lichen known from Turkmenistan and Uzbekistan, growing on twigs on Amygdalus communis, similar to Rinodina exigua, Lecania makarevicziae differs in having thicker, somewhat uplifted, warted to areolate-squamulose (vs. more or less thin, warted) and blastidiate thalli, and in having longer ascospores $((13-) 15-18(-20)[-23] \times(4-)$ 4.5-5.5(-6) $\mu \mathrm{m}$ vs. 9-13 × 4-6 $\mu \mathrm{m})$.

From Lecania alexandrae Tomin, known from mainly aspen and lime trees in Eastern European plain, Lecania makarevicziae differs in having smaller apothecia (0.5-1.5 $\mathrm{mm}$ vs. $1.2-2.5 \mathrm{~mm}$ diam.), in having a violetish brown disc (vs. reddish brown), in having permanent thalline margin, as well as in the lack of well-developed white hypothallus, in the lack of whitish pruina on apothecium disc, while ascospores have almost the same size ((13-)15-18(-20)[-23] × $4.5-5.5 \mu \mathrm{m}$ vs. $14-24 \times 4.5-7 \mu \mathrm{m})$.

Lecania viridulogranulosa (Harm.) Zahlbr., known from SW Europe and growing on trunks of deciduous trees, has also 3-septate ascospores, 8-spored asci, and although the apothecia can have the same habitus as the new species. However, it differs in having a thallus, of much smaller squamules, which are always blastidiate, as well as in having usually much smaller apothecia (0.5-1.5 mm vs. up to $0.7 \mathrm{~mm}$ ), while ascospores have somewhat the same size $((13-) 15-18(-20)[-23] \times 4.5-5.5 \mu \mathrm{m}$ vs. $12-19 \times 4-6 \mu \mathrm{m})$.

Lecania fuscella (Schaer.) Körb. has also similarities with the new species. The apothecia seems to be the same, but it differs in having whitish, thin and mostly inconspicuous thallus, in having smaller apothecia $(0.5-1.5 \mathrm{~mm}$ vs. $0.5-0.8 \mathrm{~mm}$ diam.), and asci, which are 8-16-spored.

Other examined specimens: Iran: Razavi Khorasan province, $34 \mathrm{~km}$ SW Dargaz, Cherlagh Valley, $37^{\circ} 28^{\prime} \mathrm{N}, 58^{\circ} 50^{\prime} \mathrm{E}, 1,070 \mathrm{~m}$ alt., forest on wet valley bottom, leg. M. Haji Moniri and Z. Alizadeh, 28.08.2013 (hb. M. Haji Moniri, KW-L); Razavi Khorasan province, $35 \mathrm{~km}$ on road of Quchan to Dargaz, Tagan, $37^{\circ} 35^{\prime} \mathrm{N}$, 59 $09^{\circ} \mathrm{E}, 900 \mathrm{~m}$ alt., wide valley mostly covered with rice farms and scattered trees, growing together with Caloplaca polycarpoides, C. zoroasteriorum and Megaspora aff. rimisorediata, leg. M. Haji Moniri, 13.12.2013 (hb. M. Haji Moniri, KW-L, sub Caloplaca polycarpoides). - [Turkmenistan:] [as “USSR: Turkmenica RSS:"] prope pag. Bagir non procul ab opp. Aschabad. Loco Staraja Nisa dicto, 400 m s. m. ad corticem Mori, leg. Ivan Pišút, 21.04.1975 (BRA). 


\section{*}

Acknowledgements - We are grateful to Dr László Lőkös (Budapest, Hungary) and Dr Arne Thell (Lund, Sweden) for the valuable comments to the manuscript.

\section{REFERENCES}

Andreeva, E. I. (1987): Flora sporovych rasteniy Kazakhstana. Vol. XI. Lichenes. 3. LecanoralesPhysciales. - Nauka, Almaty.

Davydov, E. A. and Printzen, C. (2012): Rare and noteworthy boreal lichens from the Altai Mountains (South Siberia, Russia). - Bryologist 115(1): 61-73. http://dx.doi. org/10.1639/0007-2745.115.1.61

Haji Moniri, M., Sipman, H. J. M. and Schultz, M. (2014): New records of lichenized and lichenicolous fungi from Northeastern Iran. - Herzogia 27: 367-376.

Kondratyuk, S. Y. and Kärnefelt, I. (1997): Josefpoeltia and Xanthomendoza two new genera in the family Teloschistaceae (Ascomycotina). - Bibl. Lichenol. 68: 1-27.

Kondratyuk, S., Zelenko, S., Nevo, E. and Wasser, S. (2007): New and rare for Israel lichenforming and lichenicolous fungi from Upper Galilee. - Ukr. Bot. J. 64: 444-453.

Kondratyuk, S. Y., Lőkös, L., Farkas, E., Oh, S.-O. and Hur, J.-S. (2015a): New and noteworthy lichen-forming and lichenicolous fungi 2. - Acta Bot. Hung. 57(1-2): 77-141. http:// dx.doi.org/10.1556/ABot.57.2015.1-2.10

Kondratyuk, S. Y., Lőkös, L., Farkas, E., Oh, S.-O. and Hur, J.-S. (2015b): New and noteworthy lichen-forming and lichenicolous fungi 3. - Acta Bot. Hung. 57(3-4): 345-382. http://dx.doi.org/10.1556/034.57.2015.3-4.7

Kondratyuk, S. Y., Lőkös, L., Halda, J. P., Haji Moniri, M., Farkas, E., Park, J.-S., Lee, B. G., Oh, S.-O. and Hur, J.-S. (2016): New and noteworthy lichen-forming and lichenicolous fungi 4. - Acta Bot. Hung. 58(1-2): 75-136. http://dx.doi.org/10.1556/034.58.2016.1-2.4

Kondratyuk, S., Lőkös, L., Tschabanenko, S., Haji Moniri, M., Farkas, E., Wang, X. Y., Oh, S.-O. and Hur, J.-S. (2013): New and noteworthy lichen-forming and lichenicolous fungi. - Acta Bot. Hung. 55(3-4): 275-349. http://dx.doi.org/10.1556/ABot.55.2013.3-4.9

Kudratov, I. and Mayrhofer, H. (2002): Catalogue of the lichenized and lichenicolous fungi of Tajikistan. - Herzogia 15: 91-128.

Makarevich, M. F. (1971): Lecania: - In: Handbook of the lichens of the U.S.S.R. 1 Pertusariaceae, Lecanoraceae and Parmeliaceae. Nauka, Leningrad, pp. 255-270.

Oxner, A. N. (1929): Zur Systematik der Gattung Lecania. - Bull. Jardin Bot. de Kieff 9: 62-63.

Seaward, M. R. D., Sipman, H. J. M., Schultz, M., Maassoumi, A. A., Haji Moniri Anbaran, M. and Sohrabi, M. (2004): A preliminary lichen checklist for Iran. - Willdenowia 34(2): 543-576. http://dx.doi.org/10.3372/wi.34.34218

Seaward, M. R. D., Sipman, H. J. M. and Sohrabi, M. (2008): A revised checklist of lichenized, lichenicolous and allied fungi for Iran. - Sauteria 15: 459-520.

Steiner, M. and Poelt, J. (1987): Drei parasitische Flechten auf Caloplaca polycarpoides. Plant Syst. Evol. 155: 133-141. http://dx.doi.org/10.1007/BF00936295

van den Boom, P. P. G. and Khodosovtsev, A. (2004): Notes on Lecania in eastern Europe and central Asia. - Graphis Scripta 16(1): 1-10.

van den Boom, P. P. G. and Zedda, L. (2000): Lecania sipmanii, a new epiphytic lichen species from Syria. - Willdenowia 30: 155-160. http://dx.doi.org/10.3372/wi.30.30115 